\title{
Religion and the New Wars Debate
}

\author{
Rodrigo Duque Estrada* \\ Renatho Costa**
}

\begin{abstract}
In this article, we analyse the converging of research on religion with the debate over the so-called 'New Wars.' Our aim is to present a state of the art of the broad literature which relates religion as an explanatory and causal factor of contemporary organised violence with the criticisms that have emerged in response to the objectivist methodology of mainstream scholarship. The work is divided into three sections, the first being a presentation of the mainstream literature, where religion is perceived as a category with causal powers. The next two sections are divided between two types of critique. The first challenges the identitarian perspective of organised violence, adding other explanatory dimensions to the analysis of contemporary conflicts. The second questions the notion of religion as an autonomous, universal and transhistorical concept, exploring genealogically the varied meanings religion may acquire and the different powers the demarcation of non-religious spheres authorises. In the concluding sections, we seek to relate those three types of methodology on religion and violence to the types of questions each one makes regarding its research object.
\end{abstract}

Keywords: religion; new wars; organised violence; religious violence; critical research on religion.

\section{Introduction}

Daily in the news media, one observes stamped headlines reaffirming the predicate of religion in the current international order: an institution or a system of creeds and rites which catalyses violence and propels much of contemporary irregular warfare. Whether the topic concerns the attacks of Islamic radicals on Charlie Hebdo or the Bataclan in Paris, the rise and fall of the Islamic State (ISIS) in Iraq and Syria, the Israeli-Palestinian conflict, the radicalisation of Buddhists in Myanmar, the actions of right-wing Christian militias in the USA, or the war between Christians and Muslims in the Central African Republic, this seems to leave no doubt that the post-Cold War era has witnessed a transformation in the phenomenon of organised violence, where international conflicts are being fought more and more in the name of religion. In this article, we analyse the converging of research

\footnotetext{
Federal University of Pelotas (UFPEL), Pelotas-RS, Brazil; rodpanzera@gmail.com. ORCID iD 0000-00027509-6911.

** Federal University of Pampa (UNIPAMPA), Santana do Livramento-RS, Brazil; renatho.costa@gmail.com. ORCID iD 0000-0002-7670-1394.
} 
about religion in International Relations (IR) with the debate of the so-called 'New Wars', presenting a state of the art of the mainstream literature and resulting critiques.

With the publication of Samuel Huntington's polemical Clash of Civilizations (1993), the debate on religion and violence started occupying a central plane of research within IR, and the attacks on the World Trade Center in 2001 only reinforced the perceived need to take religion seriously as a relevant variable in world politics for the new century. Commenting on the significance of the terrorist attacks for the study of religion in IR, Jonathan Fox and Shmuel Sandler (2004: 21) argued that this watershed event made it difficult to neglect that 'there exist religiously motivated people who seek to influence the international status quo, and that the 'intrusion of the non-West to the West was more profound than any previous event.'

Generally speaking, the years that followed the 9/11 attacks saw a 'turn to religion in IR' (Kratochvíl 2009; Kubálková 2009). A burgeoning body of analysts and specialised journals started debating, on the one hand, the power of religion in promoting either conflict or peace processes in the international system (Hayne 2007; Troy 2013), or on the other, the implications this has for the secularisation thesis - a central axiom in the social sciences which predicted the decline of religious systems with the growing process of modernisation alongside the triumph of science (Beck 2010; Hurd 2007; Philpott 2002).

This scholarship did not dismiss rhetorical proclamations which today enjoy considerable consensus in academic jargon, such as 'Religion and International Relations: The return from exile' (Petito and Hatzopolous 2003); 'The global resurgence of religion' (Thomas 2005); and 'Religion, the forgotten dimension' (Fox 2001). Religion has therefore emerged as a universal explanatory category with inherent features that confer on it notions of social agency, intentionality and causality in international affairs. Thus, phenomena classified as 'religious' may be identified objectively, bunched into statistical data, compared and analysed in such a way as to extract qualitative inferences about the difference between religious and non-religious phenomena, such as: religious and secular violence (Fox 2004a; Clarke 2014), religious and secular nationalism (Juergensmeyer 2008), and religious and secular agents in world politics (Haynes 2001).

An important line of inquiry which dialogues directly with the turn to religion in IR is the debate on the so-called 'New Wars.' According to Mary Kaldor (2001), the aims of this new type of warfare are linked to the politics of particularistic identities, religion being one of its most important dimensions. Herfried Münkler (2005) states that, besides economic factors, ethnic and religious tensions reinforce the friend-enemy distinctions of such wars. To Juergensmeyer (2008: 17), contemporary religious politics is the

result of an almost Hegelian dialectics between two competing frameworks of social order: secular nationalism (allied with the nation-state) and religion (allied with large ethnic communities, some of them transnational). The clashes between the two have often been destructive, but [...] they have also offered possibilities for accommodation. 
In this line of inquiry, research on the nature of religious conflicts and the relationship between religion and violence abound, especially regarding the topic of Islamic terrorism. However, this literature lacks an analysis that puts such interpretations in perspective. The aim of this article therefore is to present a state of the art of the broad and diffuse literature which relates religion as an explanatory and causal factor of contemporary conflicts with the critiques that have emerged in response to the objectivist hermeneutics of the mainstream literature.

The article is divided into three parts, the first one being an overview presentation of the mainstream literature. The next two parts are divided between two types of critiques. The first, internal to the New Wars debate, challenges the identitarian approach to organised violence, adding other explanatory dimensions to the analysis of contemporary conflicts in which religion appears marginal. The second, external to the debate but linked to a broader interdisciplinary agenda, questions the notion of religion as an autonomous, universal and transhistorical concept, exploring genealogically the varied meanings which religion may acquire and the different powers that the demarcation of non-religious spheres authorises, especially the legitimation of violence of the secular state. A concluding part follows after this, where we seek to relate those three methodological approaches concerning religion and violence to the types of questions each one makes regarding its object of inquiry.

\section{Religion and the New Wars}

According to former British Prime Minister Tony Blair (cited in Helm 2014), 'the battles of this century are less likely to be the product of extreme political ideology, like those of the $20^{\text {th }}$ century - but they could easily be fought around the questions of cultural or religious difference.'

As a self-declared world activist for inter-religious dialogue, Blair - who in 2008 founded the Tony Blair Faith Foundation, which was renamed in 2016 as the Tony Blair Institute for Global Change - makes an argument that is not simply based in intuitive convictions; it is otherwise easily grounded in quantitative data. A recent study from the Pew Research Center on religion and public life concluded that the parcel of countries with a high level of social hostility involving religion had reached a six-year peak in 2012 (33\% compared to $20 \%$ of the 198 countries researched in 2007). The types of hostilities which boosted this increase include: abuses against religious minorities (47\% in 2012 against $24 \%$ in 2007); violence or the threat of violence in order to impose religious norms (39\% in 2012 against $18 \%$ in 2007); harassment against women due to religious vestments (32\% in 2012 against $7 \%$ in 2007); terrorist violence related to religion (20\% in 2012 against 9\% in 2007); and sectarian or communal violence (18\% in 2012 against $8 \%$ in 2007) (Pew Research Center 2014).

These public perceptions directly reflect the proposition of a growing body of scholarship engaged in understanding the so-called 'New Wars', which include religion as a relevant factor for analysis. With broad methodological approaches and varied findings, as 
well as a diffuse line of inquiry which makes it hard to formulate any coherent or evolutionary description of the literature, what unites these investigations in a common grounding is the assertion that a 'new type of organized violence has developed, especially in Africa and in Eastern Europe, which is one aspect of the current globalized era' (Kaldor 2001: 1).

As highlighted by many of the 'New Wars' proponents, the post-Cold War period is marked by a transformation in the means and ends of organised violence (Kaldor 2001; Münkler 2005; Shaw 2002). They differentiate themselves from classical interstate warfare of the ius publicum europaeum: regular conflict among states that mutually recognise one another, encompassing clear temporal and spatial demarcations such as internal/external, combatant/non-combatant, peace/war, etc., and which had allowed, according to a notorious and controversial interpreter of this period, Carl Schmitt (2014: 103), circumscription of its worst effects and 'humanisation' of conflict, so to speak. Not only had the means of warfare been transformed with globalisation (asymmetric conflicts, the privatisation of organised violence, transnational sources of financing, and the emergent complex of state and non-state actors), but also new objectives began competing with geopolitical claims and nationalist/universalist ideologies which were characteristic of the $20^{\text {th }}$ century.

Mary Kaldor (2001: 6), a pioneer in this field, claims that ideological or territorial cleavages are being supplanted by 'emerging political cleavages between $[\ldots]$ cosmopolitanism, based in inclusive, universalist multicultural values, and the politics of particularistic identities'. Although she elaborates less on a typology of such identitarian politics and more on the historical process in which the New Wars arose, we can glimpse some clues as to how religion assumes relevance and is thereby represented in such reasoning. Kaldor (2001: 6) understands identitarian politics as a 'claim to power on the basis of a particular identity - be it national, clan, religious, or linguistic.' In opposition to old identities linked to state interest or to what she calls 'forward-looking' projects, the new particularistic politics are based in labels which 'tend to relate to an idealized nostalgic representation of the past' (Kaldor 2001: 7). The specific quality which opposes exclusionary, religious politics to cosmopolitan politics is summed up in the following argument:

These backward-looking political projects arise in the vacuum created by the absence of forward-looking projects. Unlike the politics of ideas which are open to all and therefore tend to be integrative, this type of identity politics is inherently exclusive and therefore tends to fragmentation (Kaldor 2001: 7).

Herfried Münkler (2005), another exponent in this field, points to the fact that the economic foundations of the New Wars - the change in the modus operandi of financing and articulation among actors - cannot be understood in isolation from the intertwined ideological factors. As he asserts, 'we see an ideologization of violence based primarily in religious sources' (Münkler 2005: 24). In a similar vein to Kaldor, Münkler's approach does not explain the distinctiveness of religious violence, sufficing for him such trivial notions as: the number of causalities due to attacks of religious groups has been greater, in comparison to the social-revolutionary or ethno-nationalist orientations, because 'God, 
or the Divine, provides legitimacy and perhaps even a recipient [...] and does not require any political calculus as to the maximum of damage or the maximum number of causalities that an attack should not exceed' (Münkler 2005: 113).

There is, however, an aspect in Münkler's thinking which puts the New Wars debate straight in the current discussion about the role of religious violence in world politics. Following a highly common trend among specialists in 'religious conflicts', in order to understand the differentia specifica of contemporary hostilities it is possible to establish an interpretative frame by comparing them to the so-called wars of religion of the $16^{\text {th }}$ and $17^{\text {th }}$ centuries, especially the Thirty Years Wars (Münkler 2005; Philpott 2002; Hass 2014). Such structural affinities, as has been suggested, allow one to describe today's Middle East, to take an example, by looking retrospectively to $16^{\text {th }}$ century Europe, when conflicts occurred 'in which religious-confessional connections in no way develop a minor role' (Münkler 2005: 3). This comparison supposedly sheds light on the analytical framework of the New Wars, because 'a look into that previous period is an adequate way of bringing about resemblances to the conditions under which the state is not anymore what it still wasn't back then: a monopolist of war' (Münkler 2005: 2).

Calling upon Carl Schmitt once again - a thinker whom Münkler is well acquainted with and even cites in his book - the ordaining principles of the ius publicum europaeum and its subsequent law of interstate warfare - which, it is argued, 'civilised' war restricting the idea of 'just cause' to conflict - only became possible due to a secularisation of politics in the consolidation of the modern state: 'The significance of the state consisted in the overcoming of religious wars, which became possible only in the 16th century and the state achieved this task only by a neutralization' (Schmitt 2003: 61). Hence, religion was the element that needed to succumb so that modern international politics - or better put, the Westphalian system - could triumph. This is one of the central axioms of politics guided by rational principles: the privatisation and non-interference of theological claims in the public sphere: silete theologi in munere alieno! ${ }^{1}$

For these thinkers, the nature of the New Wars of religion represents a kind of instated chaos in which the secular state loses the monopoly of organised violence: 'in fact, it can be argued that the New Wars are part of a process which is more or less reverse to the processes by which the modern states evolved' (Kaldor 2001: 5). Münkler (2005: 8) argues, in his turn, that the New Wars are wars of the disintegration of the state. This claim is put in such an acute manner that the religious factor comes to be considered even a potential threat to international society. Already in 1992, Bernard Lewis had pointed to the intrinsic 'dangers' of militant Islamic radicalism: 'Whatever doubts one may have about the ability of the fundamentalists, once in power, to achieve their declared aims, one should not underrate their capacity to gain and to use power' (Lewis 1992).

In light of such a rationale, the events of $09 / 11$ seem to represent the unequivocal fact that religion has returned from its 'exile' (Petito and Hatzopolous 2003) to occupy a central role in international politics. And more: the 'global resurgence' of religion (Thomas 2005) brings with it the registered mark of the phenomenon which should lead the research agenda on religion and violence: Islamic terrorism. Following the alarmist wave on 
the inherent 'dangers' that Islamic fundamentalism poses to the 'Westphalian synthesis,' Philpott (2002: 67) argues that

Of all the fits and starts in the arousal of public religion over the past generation, the most radical and volatile is a political theology - radical Islamic revivalism, it can be called - that directly challenges the authority structure of the international system.

Taking this into account, one may note that although the debate on the New Wars focuses more on the systemic transformations influencing the shift from classic warfare to a type of 'post-modern war' (Gray 1997), and in the conditions under which such wars foster the so-called 'local and global war systems' (Keen 2007), religion constitutes in itself a problem and an epistemological backdrop for research on this topic, raising the need for further explanation. After all, as Mark Juergensmeyer (2008: 22), a leading scholar in the field, neatly puts it, 'religious conflict is one indication of the power of religion to sanction killing. The parties in such an encounter may command a greater degree of loyalty than do contestants in a purely political war.'

To the extent that 'religious activists' are appropriating modern instruments of political power, including global networks, technology and the state machinery (Juergensmeyer 2008: 38), there is an inevitable demand that this phenomenon be understood, and its global impacts measured. Thus, it is no mere coincidence that a puissant literature arose to deal with the issue: 'In order to defeat Islamist extremism, we first have to understand it', avows an introductory charter on the website of the Tony Blair Institute for Global Change (Institute for Global Change n.d.).

To a great extent, Huntington's work is considered a watershed in contemporary studies on religious conflicts, above all for claiming that the post-Cold War era is not marked by ideological conflicts, but by cultural, civilisational confrontations whose matrix lies in religious identities such as Islamic, Confucian, and Hindu civilisations (Huntington 1993: 25). Even though Huntington's main thesis is still the object of hearty debate, many studies seem to corroborate the thesis according to which religious conflicts constitute one of the most important pillars of the desecularised world (Berger 2000; Beck 2010). Jonathan Fox's inquiries (2004a; 2004b) are in this sense revealing. ${ }^{2}$ Investigating the magnitude of religious conflicts between 1950 and 1996, he concludes that

Religious conflicts continue to be a significant proportion of all conflict and religious factors influence the dynamics of conflicts, but the more specific predictions found in Huntington's 'clash of civilizations' theory are not an accurate description of religious conflict nor of conflict in general (Fox 2001a: 70).

A crucial aspect of scholarship on religious conflicts revolves on the hermeneutic models explaining the specificity of religious violence. After all, any elaboration on religious warfare or violence stems from a simple epistemological proposition: that there is 
a domain in reality where a contingent phenomenon receives an analytic filter through which it becomes possible to observe, classify, compare, quantify and infer hypotheses about it. In other words, it is the ability of scholars to demarcate religious from non-religious violence. We cannot explore the extension of these studies here, only point out some of its analytical paths. ${ }^{3}$

What is intrinsic to the category of religion which makes its type of violence - and its peculiar dynamics like intensity, mobilisation and legitimacy - essentially distinct from secular violence? According to Jeffrey Haynes (2007: 79),

Religion is focused on the absolute and unconditional and as a result can adopt totalitarian characteristics [...] When claiming both absolute and exclusive validity religious conviction can lead to intolerance, over-zealous proselytization and religious fragmentation.

In a similar analytical vein, Juergensmeyer (1991: 114) claims that violence is endemic to religious thought due to the very nature of religion, which is based on an attempt to impose order amidst chaos:

[...] there is sometimes the perception of an encounter between the two, order and disorder; it is a struggle that is frequently imagined as proceeding on a cosmic plane. It is when this cosmic war is confused with a struggle in the social world that religious violence becomes savagely real.

To David Rapoport (1984: 674), the peculiar feature about 'sacred' violence stems from its transcendental nature: ' $\mathrm{t}$ ] he transcendent source of holy terror is its most critical distinguishing characteristic; the deity is perceived as being directly involved in the determination of ends and means.' The above-mentioned claims head towards inscribing the specificity of religious violence as distinct to other forms of organised violence. Wherever dynamics of irregular conflicts may occur in the globalised world, with social groups justifying their means of action in view of pre-ordained transcendental ends based on divine wrath or promise - perceivable, one would say, in actors such as Boko Haram, in Nigeria; Al Qaeda in the Maghreb, in North Africa; Al-Nusra Front, in Syria; and the nearly extinct ISIS, in the Levant - the need for academia to theorise about the specifically religious $d i$ mension of such conflicts supports much of the common sense inculcated in news media and public opinion. Commenting on religion and geopolitics in an opinion column on the website of the Tony Blair Institute for Global Change, Ed Husain and Ali Soufan (2017) are categorical in claiming that in the Middle East,

Muslim-Majority states remain caught between conflicting interpretations of their Islamic foundations. Across the region, sectarian theological differences are compounded by powers with ambitions of regional domination and their weaponization of religion in pursuit of political aims, a trend that shows no sign of slowing in 2017. 
Similarly, in an interview for Deutsche Welle, researcher Matthias Basedau (2017) claims that eight in every ten African conflicts have a religious dimension, where two types of religious conflicts must be distinguished:

In inter-religious conflicts, the conflict parties differ in their religious affiliation -for example, Christians and Muslims [...] This is different from theological conflicts which are mostly about religious ideas. Such conflicts can arise in majority Muslim societies, such as Mali, Somalia or Northern Nigeria.

Religion is thus widely understood as an explanatory category in which the specific quality of its violence, unlike other types of non-religious violence, is linked to claims of a 'deeper reality', which is 'absolute and unconditional,' and ultimately calling into question the central values of liberal democracy such as equality before law, the division of powers and freedom of creed. Not only do scholars perceive and theorise about this phenomenon, but increasingly, state agencies, international organisations and government officials understand contemporary conflicts from a constellation of concepts around which religion prominently appears. For example, a document from the Joint Doctrine and Concepts Centre, a think tank linked to the British Defence Ministry which is projecting Great Britain's future defence and security policy until 2030, included in its considerations an 'increasing mutual antagonism between Islamic and Western cultures' (Gutowski 2012: 88 [emphasis added]). A notorious dimension of this tendency is the creation of international public policies to deal with religious fundamentalism and to engage with the so-called 'moderate' in favour of 'positive' social change. Elizabeth Hurd (2015: 3), while critically evaluating the literature, notes that according to the conventional view of intelligence services, the 'correct' type of religion would have emancipatory potential: 'Moderate religion has the capacity to treat a variety of social ills, such as gender-based oppression and the exclusion of minorities, and a lack of development. Tolerant religion, in this view, catalyzes democratization and political pluralism.'

\section{Critical literature of the New Wars}

In this section, we present the literature which criticises the New Wars paradigm. This criticism directs its attention to both the macro-sociological explanations of 1) the unprecedented causes of violent contemporary conflicts and 2) the qualitative transformation in the means and ends of the New Wars (Malešević 2008: 98; see also Newman 2004). Here one glimpses at elements challenging many of the assumptions taken as natural in the role of religion in organised violence.

According to the sociologist Sinisa Malešević (2008), the distinction Mary Kaldor makes between identity politics (based on religion, clan, ethnicity) and ideology (nationality, cosmopolitanism, socialism) is empirically untenable. Such a distinction assumes that ideology is based in a complex system of ideas which embraces a broader totality of 
social life, while identity politics is limited only to label claims from a specific group. As he asserts,

As there is never one way of how somebody can be a member of a particular group, the identitarian language of collective solidarity is inherently political: it speaks in terms of cultural authenticity but it acts through political projects (Malešević 2008: 106).

Thus, there is no substantial ontological difference between, for instance, political projects postulating a social order without classes and those which seek to impose a society of pure ethnicity, for 'there is no identity without ideology and no ideology can successfully mobilize massive support without constructing meaningful group labels' (Malešević 2008: 107). Understanding a conflict merely as a result of identity politics based on religious labels leads ultimately to a culturalist interpretation of reality whose most immediate effect is to depoliticise it.

In his book on the sociology of warfare and violence, Malešević (2010) delivers strong criticism of what he calls the neo-Durkheimian conception of warfare, which assumes that cultural factors - like religious systems - could in themselves explain the origin and persistence of organised violence. In his view, 'cultural codes certainly make the war effort more smooth, more plausible, and even significative, but they are not responsible for creating war in itself' (Malešević 2010: 68). Far from being a causal force, cultural codes are supplementary to politically instantiated social actions (Malešević 2010: 69). Any reflection on organised violence cannot, in Malešević's terms, break away from considering the continuous processes of accumulative bureaucratisation, the ideological centrifugation of violence, which owe their existence to the historical material conditions of technological development and state centralisation, and not simply to a cultural difference such as 'religion' (Malešević 2010: 120-140).

Malešević points out four epistemological weaknesses of this naturalist conception which derives collective violence from a group's substance, for instance, an alleged syngenism between Protestants and Sunnis, whose ethnocentric grievances are sufficient causes for generating hostility towards other groups (Malešević 2010: 180). The first weakness concerns group solidarity. Instead of analysing the social processes which produce and reproduce group solidarity and homogeneity, 'it simply presumes that the mere fact of sharing similar cultural or biological markers will somehow automatically translate into effective collective action' (Malešević 2010: 181). The second refers to the reifying and essentialist implications of this type of analysis. To the extent that groups are represented homogenously and as stable entities (the notion of a 'religious conflict' captures this idea well), they seem to 'acquire individual attributes and personality traces such as will, emotions and intentions' (Malešević 2010: 182), reducing the complexity of social action into an alleged anthropomorphic unity.

The third fallacy concerns the indistinction in the naturalist rationale between war and other psychological reactions such as hostility, aggression, rage, fear, etc. Therefore, war cannot only be interpreted as an extension of a personal (or divine) dispute on a 
greater scale. Warfare, according to Malešević (2010: 183), is above all 'a social institution that reflects social structure and involves not only the actors taking part, but also connects with wider social networks and in the process legitimizes and is legitimized by political and ideological authorities.'

The last epistemological fallacy concerns the assumption that violent processes are merely linked to cultural or biological difference. Thus,

If speaking different languages, performing similar rituals or worshiping mutually incompatible deities would automatically lead to violent confrontation, then warfare would be a permanent feature of nearly all societies at all times [...] Ethnicity and nationness are dynamic social relationships and not static, primordial and fixed group properties (Malešević 2010: 184).

Malešević's approach alerts against the type of methodology which establishes a strictly narrow focus on the reality attributed to discourse and the representations actors make of themselves. Likewise, investigative reporter Mehdi Hassan (2015), in an article intitled 'How Islamic is the Islamic State?', uses the expression 'fundamental attribution error' - taken from anthropologist Lee Ross - when referring to the phenomenon in which 'we place excessive emphasis on internal motivations to explain the behaviour of others, in any given situation, rather than considering the relevant external factors.' Much analysis on the rise of ISIS part from this culturalist view which valorises actors' very own religious discourse and their eschatological conceptions of the world as interpretative variables. As Hassan (2015) puts it, "we neglect to focus on the "interests" of groups such as Isis and obsess over their supposedly messianic and apocalyptic "beliefs."

Let us take the empirical example of (the now nearly extinct) ISIS. Taking into account the mainstream approach, if the civil war in Iraq (2011-present) can be considered a religious conflict simply because there are religious and secular elements disputing power (Sunnis, Shiites, Alawites and Kurds, the latter considered secular), then, following Malešević's critique, we would arrive at a very impoverished image of reality. In more accurate accounts of the rise of ISIS, such as Patrick Cockburn's (2015) empirical investigation, we see the presence of other factors exploring the level of historical process, social structures and the articulation of many local, transnational and international actors. Cockburn (2015: 49) does not ignore the 'toxic, but efficient, combination of extremist religious beliefs with military capability', but this becomes secondary when considering broader conditioning factors, such as the 2003 US invasion in Iraq, ${ }^{4}$ the failure of the War on Terror, and the civil war in Syria (2011-present), fuelled by armaments sent by western powers that ended up in the hands of rebels, many of whom were part of radicalised movements. In fact, religion becomes a marginal element when compared to the US invasion, which to many specialists represented the true catalyser of Jihadist organisations (Stern and Berger 2015: 40).

This does not mean that symbolic representations or ideology constitute no decisive factor in the dynamics of a conflict. However, there is quite a subtle difference between 
elements which may alter the course of an armed conflict - whether the means of violence, financing methods, legitimacy or scale of intensity - and the vindication of a static causality. Nevertheless, what we understand religion to be and how this relates to social structure is still, in this case, underspecified. This, however, does not seem obvious to the analysts of contemporary religious conflicts. Within the critical sociological framework presented in this section, the research problem is no longer laid out as 'how does religion promote conflict?', or 'was there a relative increase of religious conflicts in comparison to non-religious conflicts in the last years?', or yet 'is religion one of the most significant features of the News Wars?' On the contrary, the more pertinent question to espouse would be: 'what social processes of identification and disidentification lead to political violence?'

According to terrorism studies specialist Marc Sagemen, ideology (religious or not) is in itself insufficient to explain processes of political violence, as there is no 'radicalisation' without there being first a process of in-group social identification. For him, the majority of analyses cannot account for how an ideology truly operates in articulating terrorist organisations and the way in which actors give meaning to their action:

The ideas that influence terrorists emerge from local group discussions. They are fluid and adopt to their changing context as seen from their group perspective. This context shapes the relevant elements of the ideology that are selected. In fact, we often see rapid shifts in in-group beliefs and opinions according to the context. The most relevant part of this context is out-group aggression against the in-group. Elements from the larger ideology relevant to the war between these groups are emphasized. The cumulative radicalization of languages as rivals competing with each other for leadership within the in-group justifies violence. This demonstrates that the specific ideology of the terrorists is not stable, but shifting according to the state of conflict with the salient out-group (Sageman, cited in Mckay 2014).

In this sense, even if 'Islam' is the defining trait of a political community, this cannot be seen merely as a derivative of the category of religion or the product of the 'causal powers' of religion in modern society. Here, a generic and exegetic view of Islam gives way to a notion of 'everyday' Islam, based on the agglomerated social networks of identification, language, institutions, socioeconomic context, etc. In this regard, Pasha (cited in Bosco 2009: 95) stresses that 'Muslim identities are structured less by religion than social circumstance: locality, ethnicity, class, occupation, or language.'

Paul Collier's (2000) statistical analysis of the global patterns of large-scale civil conflicts since 1965 is also instructive for a critique of the 'News Wars of religion.' As discourse about conflicts is dominated by ideas of group grievances stimulating hatred and violence, the author expected to find an intimate relationship between modalities of grievances and their incidence in conflict. Quite to the contrary, Collier concluded that economic agendas and greed opportunities are more essential to comprehending the causes of conflict and 
the motivation of actors. An interesting methodological insight he brings out is that, to the extent that rebel organisations 'embed their behaviour in a narrative of grievance, the observation of that narrative provides no informational content to the researcher as to the true motivation for rebellion' (Collier 2000: 62), for these narratives perform a strategic, functional role to these groups either from an external point of view (how conflict comes to be perceived internationally), internally (ability to recruit rebels), or for personal fulfilment (self-persuasion that violence is justified due to a larger cause and not only for material enrichment). In the issue of individual motivation for joining ISIS, for instance, Mubin Shaikh (cited in Hasan 2015), a self-declared former radical who today assesses the Canadian intelligence service affirms that 'Fear, money ... adventure, alienation and, most certainly, anger at the west for what happened in Iraq ... [also] explain why people join [Isis].'

In a perspective opposed to Collier's economic approach, Fred Halliday also rebuffs religion as a relevant factor for explaining contemporary conflicts - especially the phenomenon of 'Islamic terrorism' - by claiming that the relevant motives for engagement concern not cultural differences but instead the deeper dynamics of power. In an interview entitled 'A matter of power, not religion,' Halliday (cited in Holms 2005: 6) points out that 'religion is not what determines the political means chosen for reaching an end, but it is the political groups of today who select and utilize religion, giving it an interpretation to their current ends.' Thus, against the dominant view that would propose 'reforms' in the interior of religions and stimulate inter-religious dialogue as a solution for 'religious conflicts,' Halliday (cited in Holms 2005: 6) asserts that the issue here is more related to a need for change in the 'balance of power within states, judicial systems and in society, in order to allow alternative explanations to arise. It's a matter of power, not religion.'

\section{Religion and violence: the anatomy of a myth}

In the last section, we presented part of the literature which criticises the New Wars approach, introducing a more densely-oriented debate in sociological content which relativises more generic hypothesis on the role of religion in contemporary conflicts. Notwithstanding the inclusion of new variables of analysis, the issue of religion remains altogether seen as an unquestionable social force for these scholars - an autonomous domain of reality, distinct from other realms of social life. Malešević (2010: 82), for instance, when explaining the material conditions behind the rise of modern ideology, assumes a strict separation between what he understands by 'ideology' and 'traditional religions,' which are something apparently different, although not exactly specified:

Since the time of Machiavelli we know that secularized politics, unconstrained by religious ethics, is able [...] to generate mass popular appeal and to be extremely ruthless in the implementation of its ideological goals. In this context ideologies appear as a much more potent generator of social action than traditional religions could ever be. 
In this section, we present the Critical Studies on Religion (CSR) literature, which directly challenges the epistemological assumptions behind the binary opposition 'religious-secular' as essentially distinct domains. In general, scholars of this line of thinking engage in the historical and ideological construction of the universal category of religion and its ensuing function in the legitimation of the modern state, together with the form of violence it authorises. The idea of a social structure purveying a clean-cut essence, capable of generating agency, causing violence or peace processes, of mixing itself into politics and even defying the state's monopoly of violence - well-accepted axioms in modern social imaginary - is put under scrutiny in this modality of inquiry, for what is at stake, methodologically speaking, is a genealogical history recovering the emergence of the secular-religious conceptual binary, alongside a discursive analysis of how these concepts are continuously represented - and the effects thereof - among specialists, the news media and politics in general.

Let us start with an example that represents the general symptom of the discourse of the religion category as a universal datum. Jonathan Fox (2004b), a prominent researcher on the role of religion in international politics, introduces his study about the increase of religious nationalism and its impact in conflict as follows: 'the purpose of this study is to examine one way religion can manifest in society and in politics over a longer time period: the nexus between ethnic violence and religious nationalism' (Fox 2004b: 716 [emphasis added]).

In this passage, we can extract some of the basic premises making up the modern imaginary about religion: first, religion as a social phenomenon (either through religious institutions or individual religiosity) is not something which simply exists in, and is affected by, daily life; on the contrary, Fox sees that religion manifests in society, in the sense of irrupting, emanating, with a power to coerce actors and transform the course of events into a distinctive religious quality. The most interesting aspect to be noted here is the capacity of analysists in identifying this 'thing', religion, manifesting, and to describe it objectively. Thus, religion seen in this light is something which exists independently of who observes it, it is a de facto truth about elements composing the world, appearing to us as both self-evident and immutable.

Secondly, religion can also appear as something essentially different from both society and politics - but something which may there irrupt sporadically. Society and politics, in this sense, are seen as clearly demarcated realms of human activity corresponding to secular and rational attributes of modern life: society as a realm of self-organising groups founded upon mutual interests; politics as a space of power dispute and the imposition of views concerning the public good. This ultimately represents the assertion of domains in which reason and zeal towards the res publica are imperative, in contrast to religion, a domain inherently private, irrational, interior and which foresees a transcendental reality which cannot be empirically observed.

Finally, concerning the realm of subjective experience, which connects individual affective ties to a greater cause for which one is willing to die or kill, Fox's argument brings to light the separation between secular and religious nationalisms as also distinct realms - the 
latter with a greater propensity to perpetrate ethnic violence. The difference resides in the fact that, while secular nationalism regards a more recent historical phenomenon with a more mundane reference, religious nationalism activates absolute, incommensurable convictions. Here, the idea of a 'national identity' is taken as an objective given reference of reality, and the 'nation' seen as a factual entity. However, if we leave the common-sense jargon (which constitutes a pattern in the way to catalogue analytical data about religion and violence), we see that this distinction has no real firm ground to stand in.

Let us recall the classic definition Benedict Anderson (2008: 33) gives about the nation as being an imagined community: 'all communities larger than primordial villages of face-to-face contact (and perhaps even these) are imagined. Communities are to be distinguished not by their falsity/genuineness, but by the style in which they are imagined'. In this sense, harbouring within it imagined symbolisations (in the experiential level: lived as truth) which transcend immediate reality, it becomes difficult not to imagine that secular ideologies like nationalism, Marxism or Liberalism can also involve 'absolute' disputes as to human destiny, as well as triggering a type of potentially violent social bond. Reflecting closely on this issue, Juergensmeyer (1994: 15), in his book about religious nationalism, claims that

Secular nationalism, like religion, embraces what one scholar calls 'a doctrine of destiny'. One can take this way of looking at secular nationalism a step further and state flatly, as did one author writing in 1960, that secular nationalism is 'a religion'[...] This structural similarity between secular nationalism and religion is complemented by what I regard as an even more basic, functional similarity: they both serve the ethical function of providing an overarching framework of moral order, a framework that commands ultimate loyalty from those who subscribe to it [...] nowhere is this common form of loyalty more evident than in the ability of nationalism and religion, alone among all forms of allegiance, to give moral sanction to martyrdom and violence.

It is not uncommon for scholars to reach similar conclusions, claiming that nationalism, like any other secular doctrine, is a type of religion stemming historically from it and yet retaining its features (Smith 1999; Szakolczai 2008). However, as interesting as it may sound in Juergensmeyer's argument, the logical implications of this conceptual indistinction are not properly considered; quite on the contrary, it is merely reported as metaphors and, in the lack of a more plausible explanation, the separation between religious and secular nationalism is vigorously reinstated and we are left, as in Fox's depiction, without any further explanation about the differential quality separating religious from secular violence.

If we recapture the discussion in the last section, we see that Fred Halliday (cited in Holms 2005: 5) also subscribes to the same essentialised distinctions Fox makes, especially when he claims that 'it is a matter of power, not religion.' In this logic, religion 
apparently has nothing to do with power, or society, or politics. It is something which is beyond such organising categories of thought and of social life, though kept reserved as a matter of private faith. This reified entity can also produce disastrous consequences if confounded with the other, secular realms, as argued by 'alarmists' of the 'dangers of religion', such as the authors cited in the first section. Here one neatly sees the 'two sides' of how religion is portrayed in public discourse: either an image of an essentially peaceful, non -violent, apolitical nature only concerned with the spiritual life; or an image as something essentially irrational, prone to violence, a potentially pernicious agent causing conflicts and threatening the rational nature of the liberal, secular and non-religious national state (Fitzgerald 2015: 3-4). According to Fitzgerald,

The modern invention of generic religion, which in its ideal form ought to be private, non-political and harmless, but which sometimes reveals a different face as barbaric, irrational, violent and concerned with power, is the very condition for inscribing 'our' secular civility as being in accordance with reason and common sense (Fitzgerald 2010: 254).

Religion thus defined arises as a transhistorical and transcultural phenomenon; that is, its social functions and inner features come to be depicted unchangingly, found in every so-called world religion, although with specific cultural external expressions (Cavanaugh 2009; Asad 1993). This claim - which is a direct heritage from political liberalism and the Enlightenment - is scarcely coherent and does not survive analytical scrutiny. According to anthropologist Tal Asad (1993), the 'religion' category is also a modern invention created as a specific strategy of power - and whatever analysis one undertakes with it needs to be aware of the history of both knowledge and power under which it emerged.

In a similar deconstructive analysis, William Cavanaugh (2009: 119) points out that

There is no transhistorical and transcultural essence of religion, but at different times and places, and for different purposes, some things have been constructed as religion and some things have not [...] Instead of searching [...] for the timeless, transcultural essence of religion, therefore, let us ask why certain things are called religion under certain conditions. What configurations of power are authorized by changes in the way the concept of religion - and its counterpart, the secular - are used?

The religion category operates, then, according to this critical literature, as an influential ideological rhetoric in international politics which, by being 'constructed,' simultaneously constructs, legitimates and reproduces another, secular, domain:

By inventing a distinct, ideally privatized, sub-rational domain of 'religions' based on belief in the 'supernatural', or in another unseen 'spiritual' dimension, we have simultaneously been able to invent an equally imaginary 'real world' of natural reason which is assumed to 
underpin the material and factual domains of the state, politics and economics (Fitzgerald 2011: 13).

Let us continue with the works of Jonathan Fox. In his study about the magnitude of religious conflicts between 1950 and 1996, Fox (2004a) introduces variables to specify and accurately prove that his categories are in fact representative of the reality under analysis. One of the variables is the mensuration of whether a conflict is in fact religious:

This variable codes a conflict as religious if the two groups involved are of different religions or if the description of the conflict provided with the State Failure data set describes the conflict as being between religious and secular elements in a state (Fox 2004a: 63).

Statistical data often gives us a distorted view of the world by reducing complexity in order to obtain homogeneous and coherent analytical unities. Fox certainly acknowledges this and takes special caution to avoid false generalisations. The results of his study disavow dominant interpretations among scholars, such as Huntington's thesis about a clash of civilisations. However, his cautions are limited to secondary methodological issues such as options of scale, sample handling and the relevance of selected data. Fox is not interested in primary definitions regarding the concept of religion and the secular, which for scholars working under the CSR label are deemed primordial. After all, as Thomas (2014: 77) stresses,

How is it possible to decide if there has been a global resurgence of religion, or in what ways religion contributes to violence, or can promote peace, democracy, human rights, economic development, and humanitarianism [...] if there is no consensus on what is being studied, and what is distinctive about religion [...]?

This is not simply a matter of conceptual definition; nevertheless, Bosco (2009: 97) understands that the 'complexion and dynamics of international politics appear very different depending on how "religion" is defined. Thus, differences in statistical variables and also in qualitative inferences - e.g.: 'religion contributes to peace or to violence' - end up as differences in degree and not in form, for such results vary only within a spectrum whose common characteristic is the shared assumption about religion: we know there are religions in the world, this is an a priori given which requires no further reflexive effort. Everything else runs from this fundamental idea: this modern system of classification establishing a binary opposition between the religious and the secular as qualitatively distinctive realms.

Even more problematic, however, is the lack of a more systematic elaboration concerning the social dynamics of organised violence. For Fox there exists only an agglomeration of conflicts computed as a posteriori analytical unities ('year-conflict' unit), that is, each conflict is considered a simple and closed totality, stripped of its historical particularities and any consideration of the social processes of each conflict and the inter-connections with local, transnational and global vectors of power. The function of variables comes into play to avoid qualitative distortions in terms of both generalisation and comparison. 
However, the only qualitative variable Fox introduces to define a conflict as religious, as shown above, is if the two groups involved are of different religions or among religious or secular elements within a state. This appears to him to be sufficient in transforming the myriad of post-World War II conflicts into those total and enclosed analytical units: for each year-conflict unit, Fox observes a religious conflict.

Theoretically, this is a phenomenon for which one identifies an independent variable - religion - and takes it as a relevant cause; hence any prognostics, as well as prescription, must take this variable into consideration to account for the totality of its content. If a conflict is motivated by multiple factors (let's assume: politics, economics, culture) in which religion stands as only one - not the foremost - of relevant factors in explanation, it becomes extremely hard and appellative to reduce this conflict per se to being religious. Therefore, for a conflict to be only religious there must be religious causes (motor of agency and behaviour) at play, independently of what this comes to mean, and not only religious justifications (vehicle for outrage). Resuming Fox's analysis, which seeks to evaluate if the relative and absolute number of religious conflicts since World War II have increased, if they are more intense than other types of conflict and if any religion in specific took part more in conflicts than others, we soon come to terms with the fallacy of such homogenous analytical units. Fox (2004a: 63) himself has reservations about the limits of collected data for analysis,

There is no data that allows the study to control for other factors or test for causality. Nor does that fact that a conflict is between groups of different religions necessarily mean that the conflict is because of these differences. As a result, any conclusions regarding causality can only be based upon implication.

Thus, if there is no way of affirming that the only presumably consistent variable (for considering a conflict as religious) is actually present within the data the author uses for computing religious conflicts, how can we ultimately attest to the distinctive quality separating religious from non-religious conflicts in such a way that the latter can be grouped, compared and inferred? ${ }^{5}$ Fox not only ignores the conceptual issue as a priori data, but compromises all his statistical analysis assuming that, ceteris paribus, the mere existence of groups from different religions, on the one hand, or of clashing religious and secular elements, on the other, suffices to codify a conflict as religious.

If we were to apply Fox's variables (which are a good indicator of the overall average) to analyse the Iraq civil war and the rise of ISIS, this would mean reducing all its complexity to what the news media and the implicated actors strategically blaze: that it is a religious war between Sunnis and Shiites regionally, and an Islamic Jihad against the secular West globally. This is the widely propagated image. According to a commentator,

when the gap between Sunni and Shia comes down to a theological dispute originating in the seventh century, when the Islamic State declares its defining mission to be the restoration of a caliphate from the same period, then it is tempting to believe this is indeed the 
curious fate of our supposedly modern era - that we are being drawn back to a medieval or pre-medieval world of holy war and wholesale slaughter in the name of religion (Freedland 2014).

Peter Bergen, a CNN national security analyst, thus echoes this idea according to which Islam is the true issue behind such conflicts, instead of any type of socioeconomic deprivation such as unemployment or inequality: 'ISIS may be a perversion from Islam, but Islamic it is' (Bergen 2015). Bergen subscribes to a world view in which there is a unique essence in each religion (that which makes Islam in its purity not corrupted, a religion of 'peace,' as one might say of any other religion), and that the problem ultimately resides in a distortion or bad interpretation of the Quran and its sacred doctrines, shifting it thus to a fundamentalist version radically prone to violence.

What solution does a reputable national security analyst such as Bergen point out to make decision makers in Washington sensitive to this issue? Evidently, it becomes a deductive, not investigative, matter: '[...] the only truly effective challenges to this reasoning must come from Islamic leaders and scholars who can make the theological case that ISIS is an aberration. This, too, is an Islamic project; it is not a jobs project' (Bergen 2015).

This approach patently echoes a powerful discursive and securitarian way of dealing with religion and shaping its contours in such a way that it can accommodate governance regimes under which religion can be closely monitored, religious leaders be seen as unconditional allies of the West, and, above all, avoid anomalies in international politics - a distinctively rational and secular realm where dialogue and tolerance should prevail. To former President Barack Obama, the issue of religious freedom appeared to be central to his foreign policy as, according to him, those who 'don't support such rights sow the bitter seeds of instability, violence, and extremism. Therefore, religious freedom is deemed most relevant to our national security' (Baker 2014).

Notwithstanding the popularity of such claims and the way in which they are fixed in the popular imaginary as de facto issues of the nature of things, if we follow the proposal of the critical scholars of religion studies, we start to understand the 'myth of religious violence.' Cavanaugh's (2009: 4) elaboration of this is worth citing:

The attempt to create a transhistorical and transcultural concept of religion that is essentially prone to violence is one of the foundational legitimating myths of the liberal nation-state. The myth of religious violence helps to construct and marginalize a religious Other, prone to fanaticism, to contrast with the rational, peace-making, secular subject. This myth can be and is used in domestic politics to legitimate the marginalization of certain types of practices and groups labeled religious, while underwriting the nation-states' monopoly on its citizens' willingness to sacrifice and kill. In foreign policy, the myth of religious violence serves to cast nonsecular social orders, especially Muslim societies, in the role of villain. They have not yet learned to remove the dangerous influence of religion from political 
life. Their violence is therefore irrational and fanatical. Our violence, being secular, is rational, peace making, and sometimes regrettably necessary to contain their violence. We find ourselves obliged to bomb them into liberal democracy.

To conclude, if one agrees that there are clear methodological limitations to the mainstream vision of religious violence and the New Wars, it would be unwise not to ask: how can statistics taken from the database available on Failed States, with a unique added variable, be considered a reliable index for evaluating contemporary 'religious conflicts' and the 'function of religion' in the $21^{\text {st }}$ century? How can we safely infer or compare the 774 year-conflicts of ethnic wars, of which $47 \%$ are deemed religious; the 264 year-conflicts of genocide, of which $25.5 \%$ are deemed religious; and the 359 year-conflicts of revolutionary wars, of which 19.5\% are deemed religious (Fox 2004a: 66) from 1950 to 1996? What type of qualified deduction will 'consumers' of such studies - international organisations, governmental agencies, politicians, all avid to support their public policies in scientific assurance -reach if 'overall, religious conflicts tend to be more intense than nonreligious ones' (Fox 2004a: 70)? And even more relevantly, as these are the data that constitute our view about facts in the world, how are we to reliably decide that there was a 'resurgence of religion in IR' (Thomas 2005), that religion 'came back from its exile' (Petito and Hatzopolous 2003), that it is the 'forgotten dimension' of world politics (Fox 2001) - the trending topics which fill academic conference halls and instil decision makers with varied perceptions?

\section{Conclusion}

In this research, we presented the debate that posits the subject of religion and violence as a central axis of the New Wars literature. After illustrating the main arguments of the mainstream approach, which understands religion as a relevant category for interpreting the phenomenon of contemporary organised violence and its particularly intensive dynamics - based in 'identity politics' about 'absolute' issues of 'human life' - we introduced some internal criticisms of this from the sociology of New Wars. Here, authors consider other broader, explanatory variables challenging the idea that conflicts can be caused by matters of religious difference or radicalism, and accounting for such conflicts in the light of complex social dynamics and irreducible historical processes.

In the last section, we presented a broad and emerging critical literature about the study of religion and its value for the New Wars debate, showing the limitations of both the first and second approaches. In this line of inquiry, religion - and its binary other, 'secular' - appear as historically constructed categories performing an ideological function in the legitimation of the state and its peculiar type of violence. When analysing the representation of religion, it becomes imperative to trace the power-oriented practices of demarcating religious from non-religious domains, as well as the political effects this entails.

Seen from a broader landscape, we can conclude that the three different methodological approaches considered here can be compared through the type of questioning each 
one makes concerning its object of inquiry. In the mainstream literature, the appropriate type of question seems to be: 'how does religion affect conflict and how is it possible to explain contemporary religious conflicts'? In the critical sociological literature, the most appropriate question is: 'what social processes of identification, exclusion and radicalisation take organised groups to assume repertories of political violence, and how do religious labels reinforce such dynamics'? Finally, taking Hurd's (2007: 16) proposal, the appropriate question to be asked in the last literature of critical religion studies is: 'How do processes, institutions and states come to be understood as religious versus political, or religious versus secular, and how might we ascertain the political effects of such demarcation?'

\section{Notes}

1 'Theologians should remain silent within foreign walls!', a famous expression by Alberico Gentilli, known as one of the fathers of modern International Law.

2 Fox's work will be further analysed in a following section.

3 For a state of the art of studies on religious violence, see Henne (2010).

4 From 2003 to 2011, an estimation of over 400,000 people died as a result of war-related causes due to US occupation. See BBC News (2013).

5 In another, similar study, Fox (2004b: 715, emphasis added) claims notwithstanding that religion is 'becoming an increasingly significant cause of conflict.'

\section{References}

Anderson, Benedict. 2008. Comunidades Imaginadas: Reflexões sobre a origem e a difusão do nacionalismo. São Paulo: Companhia das Letras.

Asad, Tal. 1993. Genealogies of Religion: Discipline and Reasons of Power in Christianity and Islam. Baltimore: The Johns Hopkins University Press.

Basedau, Matthias. 2017. 'Religious conflicts on the rise in Africa'. Deutsche Welle, 23 September. At https://www.dw.com/en/religious-conflicts-on-the-rise-in-africa/a-40645771 [Accessed on 6 July 2018].

BBC News. 2013. 'Iraq study estimates war-related deaths at 461,000'. 16 October.

At https://www.bbc.com/news/world-middle-east-24547256 [Accessed on 28 January 2016].

Beck, Ulrich. 2010. A God of One's Own: Religion's Capacity for Peace and Potential for Violence. Cambridge: Polity.

Bergen, Peter. 2015. “Jihadi John': The bourgeois terrorist.' Cables News Network (CNN), 27 February. At http://edition.cnn.com/2015/02/19/opinion/bergen-terrorism-root-causes/index.html [Accessed on 28 January 2016].

Berger, Peter L. 2000. 'A Dessecularização do Mundo: uma visão global'. Religião e Sociedade 21 (1): 9-24.

Bosco, Roberto M. 2009. 'Persistent orientalisms: The concept of religion in International Relations.' Journal of International Relations and Development 12 (1): 90-111. 
Cavanaugh, William T. 2009. The Myth of Religious Violence: Secular Ideology and the Roots of Modern Conflict. New York: Oxford University.

Clarke, Steve. 2004. The Justification of Religious Violence. Oxford: John Wiley \& Sons.

Collier, Paul. 2000. 'Doing well out of war: An economic perspective.' In Marts Berdal and David Malone (eds), Greed and Grievance: Economic Agendas in Civil Wars. Ottawa: Lynne Rienner, pp. 61-74.

Fitzgerald, Timothy. 2011. Religion and Politics in International Relations: The Modern Myth. London: Continuum.

2015. 'Critical Religion and critical research on religion: Religion and politics as modern fictions.' Critical Research on Religion 0 (0): 1-17.

Fox, Jonathan. 2004a. 'Religion and state failure: An examination of the extent and magnitude of religious conflict from 1950 to 1996.' International Political Science Review/Revue international de science politique 25 (1): 55-76.

.2004b. 'The rise of religious nationalism and conflict: Ethnic conflict and revolutionary wars, 1945-2001.' Journal of Peace Research 41 (6): 715-731.

2001. 'Religion as an overlooked element of international relations.' International Studies Review 3 (3): 53-73.

Fox, Jonathan and Shmuel Sandler (eds). 2004. Bringing Religion Into International Relations. New York: Palgrave Macmillan.

Freedland, Jonathan. 2014. 'The Islamic State nightmare is not a holy war but an unholy mess.' The Guardian, 8 August. At https://www.theguardian.com/commentisfree/2014/aug/08/islamic-statenightmare-not-holy-unholy-mess-iraq [Accessed on 6 July 2018].

Gray, Chris H. 1997. Postmodern War: The New Politics of Conflict. New York: The Guilford Press.

Hasan, Mehdi. 2015. 'How Islamic is the Islamic State?' New Statesman, 10 March. At http://www. newstatesman.com/world-affairs/2015/03/mehdi-hasan-how-islamic-islamic-state [Accessed on 4 February 2016].

Haynes, Jeffrey. 2007. Religion and Development: Conflict or Cooperation? New York: Palgrave McMillan.

2001. 'Transnational religious actors and international politics.' Third World Quarterly 22 (2): 143-158.

Henne, Peter S. 2010. 'Constructing cosmic war: Rhetorical outbidding and religious violence.' Paper delivered at the 2010 International Studies Association (ISA) Annual Convention 'Theory vs. Policy? Connecting Scholars and Practitioners.' New Orleans, 17-20 February.

Helm, Toby. 2014. 'Extremist religion is at root of 21st-century wars, says Tony Blair.' The Guardian, 25 January. At http://www.theguardian.com/politics/2014/jan/25/extremist-religion-wars-tony-blair [Accessed on 2 February 2016].

Holms, Adam. 2005. 'A matter of power, not religion.' LSE Magazine. At http://www.lse.ac.uk/ alumni/LSEConnect/LSEMagazine/pdf/winter2005/Power_Spread.pdf [Accessed on 5 February 2016].

Huntington, Samuel P. 1993. 'The clash of civilizations?' Foreign Affairs 72 (3): 22-49.

Hurd, Elizabeth S. 2015. Beyond Religious Freedom: The New Global Politics of Religion. Princeton: Princeton University Press. 
2007. The Politics of Secularism in International Relations. Princeton: Princeton University

Press.

Husain, Ed and Ali Soufan. 2017. Religion, Conflict, and Geopolitics in 2017. Tony Blair Institute for Global Change. At https://institute.global/insight/co-existence/religion-conflict-and-geopolitics-2017 [Accessed on 8 November 2018].

Institute for Global Change. n.d. At https://institute.global/co-existence [Accessed on 6 July 2018]. Juergensmeyer, Mark. 2008. Global Rebellion: Religious Challenges to the Secular State, from Christians Militias to Al Qaeda. Berkeley: University of California Press.

1991. 'Sacrifice and cosmic war'. Terrorism and Political Violence 3 (3): 101-117.

. 1994. The New Cold War? Religious Nationalism Confronts the Secular State. Berkeley: University of California Press.

Kubálková, Vendulka. 2009. 'A “turn to religion” in International Relations?' Perspectives 17 (2): 13-42. At http://www.ceeol.com/aspx/issuedetails.aspx?issueid=19d8a484-f7c6-47a0-a405-9492e944f47d [Accessed on 3 February 2015].

Kaldor, Mary. 2001. New and Old Wars: Organized Violence in a Global Era. Stanford: Stanford University Press.

Keen, David. 2007. 'Sistemas de guerra: local y global.' Revista Académica de Relaciones Internacionales 6: 1-46.

Kratochvíl, Petr. 2009. 'The Religious Turn in IR: A brief assessment.' Perspectives 17 (2): 5-12. At http://www.ceeol.com/aspx/issuedetails.aspx?issueid=19d8a484-f7c6-47a0-a405-9492e944f47d [Accessed on 2 February 2015].

Mckay, Al. 2014. 'Interview - Marc Sageman.' E-International Relations, 20 November. At http:// www.e-ir.info/2014/11/20/interview-marc-sageman [Accessed on 5 February 2016].

Malešević, Siniša. 2008. 'The sociology of New Wars? Assessing the causes and objectives of contemporary violent conflicts.' International Political Sociology 2: 97-112.

2010. The Sociology of War and Violence. Cambridge: Cambridge University Press.

Münkler, Herfried. 2005. The News Wars. Cambridge: The Polity Press.

Newman, Edward. 2004. 'The 'New Wars' debate: A historical perspective is needed.' Security Dialogue 35 (2): 173-189.

Petito, Fabio and Pavlos Hatzpolous (eds). 2003. Religion in International Relations: The Return from Exile. Nova York: Palgrave Macmillan.

Pew Research Center. 2014. 'Religious hostilities reach six-year high.' Religion \& Public Life, 14 January. At http://www.pewforum.org/2014/01/14/religious-hostilities-reach-six-year-high/ [Accessed on 8 March 2016].

Philpott, Daniel. 2002. 'The challenge of September 11 to secularism in International Relations.' World Politics: A Quarterly Journal of International Relations 55 (1): 66-95.

Rapoport, David. 1984. 'Fear and trembling: Terrorism in three religious traditions.' The American Political Science Review 78: 658-677.

Schmitt, Carl. 2014. O nomos da terra no direito das gentes do jus publicum europaeum. Rio de Janeiro: Contraponto/PUC-Rio. 
Shaw, Martin. 2002. 'Risk-transfer militarism, small massacres and the historic legitimacy of war.' International Relations 16 (3): 343-359.

Smith, Anthony. 1999. 'Ethnic election and national destiny: Some religious origins of nationalist ideals.' Nations and Nationalism 5 (3): 331-55.

Stern, Jéssica and J M Berger. 2015. O Estado Islâmico: Estado de terror. Amadora: Vogais.

Szakolczai, Arpad. 2008. 'The spirit of the nation-state: Nation, nationalism and inner-wordly eschatology in the work of Eric Voegelin.' International Political Anthropology 1 (2): 193-212.

Thomas, Scott. 2014. 'The religious turn in the study of International Relations.' The Review of Faith \& International Affairs 12 (4): 76-82.

2005. The Global Resurgence of Religion and the Transformation of International Relations:

The Struggle for the Soul of the Twenty-First Century. New York: Palgrave MacMillan.

Troy, Jodok. 2013. 'The power of the zealots: Religion, violence, and International Relations.' Journal of Religion and Violence 1 (2) 217-233.

\section{About the authors}

Rodrigo Duque Estrada received his MA in International Relations in the San Tiago Dantas Graduate Program (UNESP, UNICAMP, PUC-SP) with the dissertation entitled 'From the Political to Security and back again: Carl Schmitt in Critical Security Studies.' He is currently substitute Professor of International Relations at Federal University of Pelotas (UFPel). His research topics include political philosophy, religion and international relations, the Western Sahara conflict and international security. He directed and produced the documentaries 'A Thread of Hope: Independence of War in Western Sahara' (2017) and 'School without Censorship' (2018). He is co-coordinator of GAE-OMAM (Strategic Analysis Group - Middle East and Muslim Africa) and founder of Nomos - Independent Publishing House and Film Company.

Renatho Costa has a Bachelor in International Relations (FASM-SP), as well as a Master and $\mathrm{PhD}$ in Social History (FFLCH-USP). He is a specialist in Middle East politics and a professor of International Relations at the Federal University of Pampa (UNIPAMPA). He is coordinator of GAE-OMAM (Strategic Analysis Group - Middle East and Muslim Africa). His publications include the book The Ayatollahs and the fear of the Islamic Republic of Iran (Porto de Ideias, 2017) and the articles 'Iran's post-revolution government model and the challenges to its functioning' (Revista Litteris, 2016), 'The Western construction of the Middle East as an instrument of International Relations' (Revista Esboços, 2016) and ' 36 years of stigmatization: Iran that few see' (Mundorama, 2015). 


\section{Religião e o Debate de Novas Guerras}

Resumo: Nese artigo, analisaremos a pesquisa convergente sobre religião com o debate sobre as chamadas 'Novas Guerras.' Nosso objetivo é apresentar um estado de arte da ampla literatura a qual relacione religião como um fator explicativo e causal da violência organizada contemporânea, bem como as críticas que surgiram em resposta à metodologia objetivista de uma escola dominante. $\mathrm{O}$ trabalho é dividido em três seções, a primeira sendo uma apresentação da literatura dominante, onde religião é percebida como uma categoria com poderes causais. As próximas duas seções são divididas em dois tipos de crítica. A primeira desafia a perspectiva identitária da violência organizada, adicionando outras dimensões explicativas à análise de conflitos contemporâneos. A segunda questiona a noção de religião como um conceito autônomo, universal e transhistórico, explorando genealogicamente os variados significados que a religião pode adquirir e os diferentes poderes que a demarcação de esferas não-religiosas autoriza. Nas seções finais, procuramos relacionar esses três tipos de metodologia sobre religião e violência aos tipos de questões que cada uma faz em relação ao seu objeto de pesquisa.

Palavras-chave: religião; novas guerras; violência organizada; violência religiosa; pesquisa crítica sobre religião.

Received on 27 February 2018, and approved for publication on 6 September 2018. 